\title{
PREHISTORIC ATACAMEÑO CERAMIC STYLES AND CHRONOLOGY REASSESSED
}

\author{
UNA RECONSIDERACIÓN DE LA CRONOLOGÍA Y \\ LOS ESTILOS CERÁMICOS PREHISPÁNICOS ATACAMEÑOS
}

\author{
Emily Stovel ${ }^{1}, 2$
}

\begin{abstract}
Archaeology in San Pedro de Atacama (northern Chile) contributes significantly to our understanding of the Middle Horizon Tiwanaku polity, its iconography, regional interaction spheres, and other pivotal themes in Andean Studies. New AMS C14 dates, however, allow us to revisit San Pedro chronological phases and the associated ceramics that often define them. This paper extends previous important contributions to ceramic analysis in the area by presenting the ceramic material found in newly dated tombs and the temporal relationship of red, black, and grey polished vessels. The results suggest that these key San Pedro ceramic styles may be more contemporary in time than previously thought. Color variation may therefore be the result of different symbolic and contextual uses rather than temporal production developments. This leads to a reevaluation of the accepted phase structure as a linear sequence of key ceramic types and of the current understanding of cultural fluorescence during the late Formative and Middle Period (ca. AD 100-900).
\end{abstract}

Key words: San Pedro de Atacama, chronology, ceramic styles, mortuary archaeology, seriation.

La arqueología de San Pedro de Atacama (norte de Chile) contribuye fuertemente a nuestra comprensión del Horizonte Medio, el Estado de Tiwanaku, su iconografía, las redes de intercambio regional, y otros temas andinos centrales. Sin embargo, nuevas fechas radiocarbónicas AMS nos permiten retomar el tema de la cronología arqueológica local, sus fases, y los tipos cerámicos que las sustentan. El presente trabajo extiende importantes contribuciones anteriores sobre la cerámica arqueológica local presentando el ajuar cerámico de estas tumbas recientemente fechadas y revisando la relación cronológica de los tipos rojo, negro y gris pulidos. Los resultados indican que estos estilos diagnósticos sampedrinos fueron más contemporáneos y que las variaciones de color posiblemente correspondieron a usos y significados sociales en vez de temporales. Por ende, se reconsidera la estructura lineal de la cronología actual y el carácter de la florescencia cultural del Formativo Tardío y el periodo Medio (100-900 d.C.).

Palabras claves: San Pedro de Atacama, cronología, estilos cerámicos, arqueología mortuoria, seriación.

As absolute dating has long been available and improved by reexamination of carbon curves, one could assume the near universal application of such techniques to chronological sequences throughout the world. The juxtaposition of absolute dates with seriated archaeological objects and contexts (i.e., sites or tombs), however, remains common today (Buck and Sahu 2000; Crombé, Sergant et al. 2009; Crombé, Van Strydonck et al. 2009; De Mulder et al. 2008; Finkelstein and Piasetzky 2010; Müller 2009; Renfrew 1973). Similar chronological revision continues or remains pending in areas where appropriate materials or funds are lacking.

Such is the case in San Pedro de Atacama (Figure 1), northern Chile. Formed by a series of small communities at the confluence of two rivers in an arid desert, San Pedro was and is a pivotal locus of human occupation and interaction (Berenguer 2004; Gundermann 2004; Núñez and Dillehay 1995). Desert aridity has preserved material culture usually lost to decomposition, so San Pedro archaeology has provided unique insight into important social entities such as Tiwanaku through archaeological textiles (Oakland Rodman 1992; Uribe and Agüero 2001, 2004) and wooden snuff tablets (Llagostera 2006; Torres 2001) unavailable elsewhere. Archaeological discussion of Tiwanaku presence in the region has grown significantly since the late 1970s (Berenguer 1978, 1998, 2000; Berenguer and Dauelsberg 1989; Berenguer et al. 1980; Costa et al. 2004; Knudson 2007, 2008; Lechtman and MacFarlane 2005; Oakland Rodman 1992; Torres-Rouff 2002, 2008;

\footnotetext{
1 Instituto de Investigación Arqueológica y Museo Gustavo Le Paige, Universidad Católica del Norte, San Pedro de Atacama, Chile. stovele@ucn.cl

2 Department of Anthropology, Ripon College, 300 Seward St. Ripon, WI, EE.UU. stovele@ ripon.edu
} 


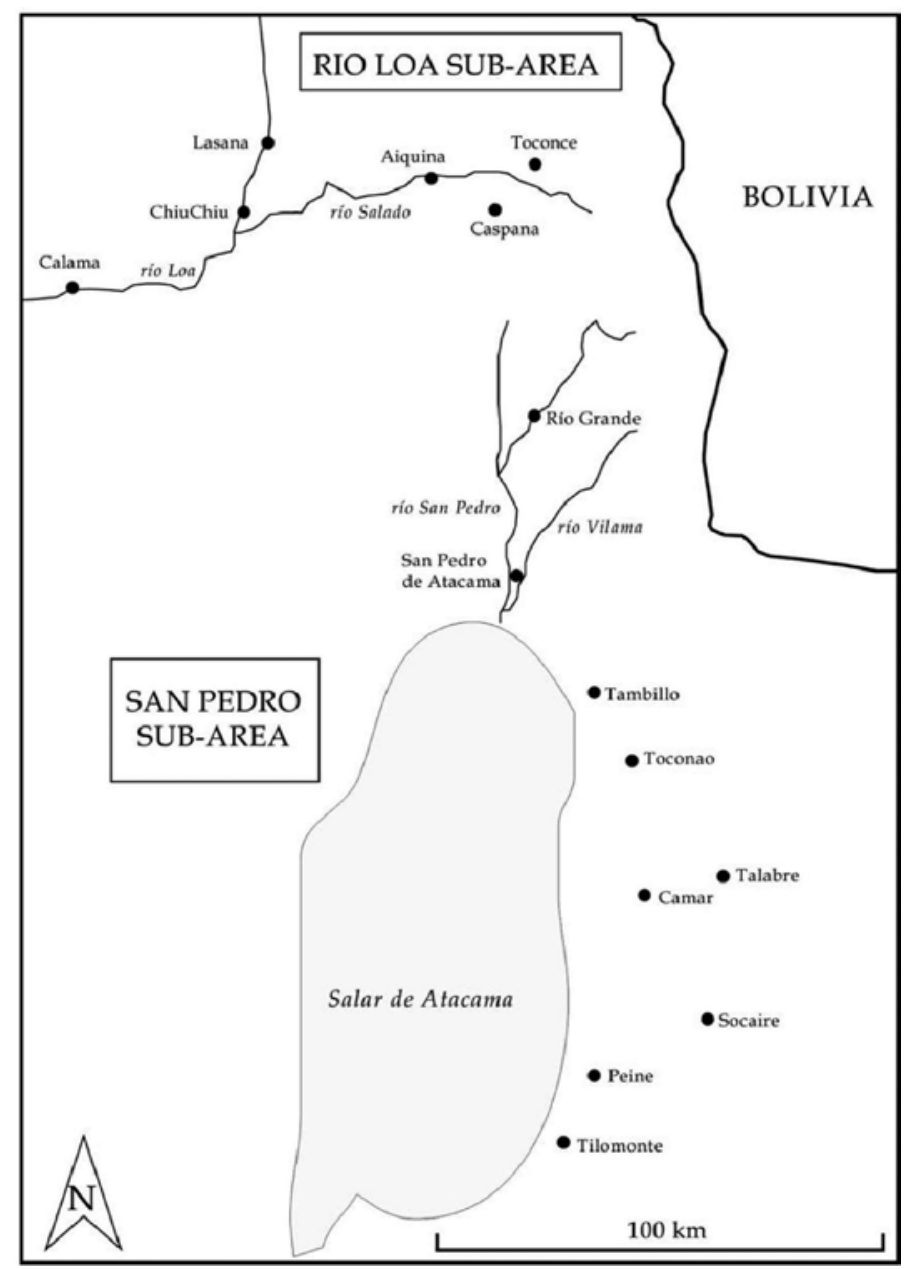

Figure 1. Río Loa and San Pedro de Atacama.

Las subregiones del río Loa y San Pedro de Atacama.

Uribe and Agüero 2001, 2004), thereby influencing wider understandings of the nature of this regional polity (Goldstein 2005:91-99; Stanish 2003:192193; Stanish et al. 2010).

The power of this contribution depends on a strong chronological base, of course. Whereas suitable material is available locally, absolute dating has been sporadic or has occurred principally on residential remains (although see Agüero 2005; Llagostera and Costa 1999; Núñez 1976; Sinclaire 1985). Archaeology relies on a useful relative chronology developed through tomb seriation and ceramic classification. Pioneering work to develop local sequences (Le Paige 1963; Núñez 1965; Orellana 1963, 1964; Tarragó 1976, 1989; Thomas et al. 1984) focused primarily on key late Formative and Middle Period (AD 100-900) burial ceramics: red and black polished wares followed by incised and thicker greywares. This sequence was generally supported by thermoluminescent (TL) dates of museum ceramics (Berenguer et al. 1986; 1988). More recent work has greatly improved our understanding of material and cultural life during each phase of the chronological sequence from the Formative to Late Periods (Agüero and Uribe 2011; Nielsen et al. 2006; Núñez et al. 2006; Uribe 2002, 2006, 2009; Uribe and Adán 2005; Uribe and Agüero 2004; Uribe et al. 2002, 2004).

Here I use new AMS dates (Hubbe and TorresRouff 2011; Hubbe et al. 2011) to reexamine the temporal ranges assigned to emblemic burial ceramic types. At first glance, these preliminary results contest accepted relationships between key styles during the late Formative and early Middle 
Period. More so, however, they confirm what we can see in a range of similar archaeological studies: the use of absolute dates often frees ceramic variation from its function as a marker of temporal change and highlights the multiple meanings and roles ceramics can take.

To begin, then, the next section will briefly examine this wider world of chronological revision, followed by a summary of the accepted typochronology used in San Pedro de Atacama. I then outline the source of these new AMS dates and the methods used to tie them to burial contexts using excavation notes recorded by Father Le Paige during the 1950s and 60s. Although the results presented here are narrow in scope, they open a larger field of contemplation for ceramic studies in the future.

\section{Reexamining Ceramics, Revising Chronologies, and San Pedro Archaeology}

Absolute dating is used in conjunction with frequency seriation where sites, contexts, assemblages and other loci are assigned to segments of time relative to others with respect to the proportion of diagnostic artefacts they hold. Ceramics, persistent in time while malleable in their response to aesthetic and social changes, have long been favored candidates for building these sequences (Duff 1996; Dunnell 1970; Kroeber 1916; Lyman et al. 1998; Petrie 1899; Rice 1987:146-147; Steponaitis 1983). Absolute dating, previously prohibitively expensive to use abundantly, served to orient seriated sequences and fix phases or periods in actual time. In a subsequent step, while establishing ranges of occupation for cemeteries or villages, researchers assigned dates according to the date ranges for ceramics found within them. This is particularly useful in burial contexts which are assumed to be "closed finds", behavioral units where each element dates to the same moment of burial (i.e., Steponaitis 1983:82; for a contrasting perspective, see Olivier 1999).

While one might think adjusting relative stylistic ceramics sequences with absolute dates in recent times means correcting or confirming date ranges, much more is visible in the literature. The first impact, by no means a new one, is to demonstrate contemporaneity of contexts, assemblages, or types (i.e., Crombé, Van Strydonck et al. 2009; Müller 2009; Olivier 1999). This undermines the assumption that the objects used are diagnostic with respect to time and that the material combinations or attributes used (for typochronological units) are ordered in a linear sequence. Objects and contexts may have chronological, functional, and symbolic meanings (i.e., Ashley 2010). Similar behaviors may have complementary but different material expressions during one time period (Crombé, Van Strydonck et al. 2009:106).

In the case of San Pedro de Atacama, the archaeological record presents a series of problems to the archaeologist interested in ordering remains according to time. Although situated in an extremely dry desert where archaeological remains are subject to processes of deflation, the Vilama and San Pedro Rivers also flood periodically. Thus archaeological remains are both subject to compaction into surface palimpsests as wind removes interstitial sand deposits (see a similar case in Beresford-Jones et al. 2009), and/or can be mixed by alluvial action (Agüero and Uribe 2011). Domestic contexts, then, often display an entire occupation history on their surfaces.

In addition, the formidable archaeological collection that forms the basis of San Pedro scholarship on local prehistory is the product of keen amateur archaeologist Gustavo Le Paige, a Jesuit priest, who recovered 6,000 graves between the early $1950 \mathrm{~s}$ and his death in 1980. Father Le Paige was very interested in crania (Le Paige 1966; Le Paige and Larraín 1961) and his tombs are identified by their cranial number. Each burial unit is listed in his notes as grave goods associated with single or multiple individuals (Hubbe et al. 2011). Le Paige's lack of excavation experience may have led to some confusion of discrete burial contexts into what he saw as multiple graves, especially in cases where individuals were buried in very close spatial association (as in the Casa Parroquial site, Téllez and Murphy 2007). The direct temporal association of a single buried individual with specific objects such as ceramic vessels is less reliable in the case of graves where multiple individuals are listed together. Discussion below explores this problem and how it impacts the results presented here.

Finally, upon Le Paige's death, tomb lots were disassembled and not recorded (Hubbe et al. 2011); therefore it is currently impossible to examine vessels from most graves. Much work is dedicated to assigning accepted type classes to the drawings done by Le Paige in his notebooks. The present paper constitutes a preliminary step in this direction by considering ceramic evidence tied to a new set of 
absolute dates acquired from human remains in an oasis-wide chronological study (Hubbe and TorresRouff 2011; Hubbe et al. 2011). It is concerned, therefore, with ceramic developments in the ritual funerary sphere. None of the vessels mentioned here were able to be examined directly for this study because of this problem with disassociation. Even so, the data presented here also bring to light vessels mentioned in Le Paige's notes, but not preserved in the museum's collection, because they were found fragmented in situ and were not reassembled but stored mixed together in large boxes.

\section{Chronologies and Ceramics in San Pedro de Atacama}

Le Paige and early scholars in San Pedro proposed a basic ceramic classification and key sequence, ratified at an International Archaeological Congress held in San Pedro de Atacama in 1963. Gustavo Le Paige (1964), Mario Orellana (1963, 1964), Lautaro Núñez (1965), and later Carlos Thomas, Claudio Massone and Antonia Benavente (1984) all provided studies that organized Atacama ceramic style and its variation into temporal phases. The currently accepted local ceramic chronology is provided in Table 1. It is based chiefly on the work of Myriam Tarragó, who undertook a 20 year study of tomb contexts, ceramic variation, and regional interaction.

Tarragó's work (1989) seriated 1442 San Pedro tombs according to recurrent material combinations employing three external chronological markers: Tiwanaku, Inka and Colonial objects, stratigraphic relationships of superposition between tombs, and $40 \mathrm{TL}$ dates provided by Berenguer and colleagues (1986; 1988). Tarragó (1976) worked principally with the seven ceramic types: Rojo Pulido (RP; Figure 2), Negro Pulido (NP; Figure 3), Negro Grabado (NGR), Rojo Grabado (RGR), Gris Pulido Grueso (GPG; Figure 4), Rojo Alisado (RA), and Gris Alisado (GA). Their definition and co-occurrences in 38 cemeteries constitute the core of her widely adopted chronology. Tarragó (1989) used shape classes to organize local ceramics. Negro Pulido burial vessels, for instance, are divided into 16 groups according to their geometric forms. There is internal chronological difference between shape classes, such as the Sequitor Phase Negro Pulido forms with straight rims (NPI, NPIII, NPV, NPIVNPVII, NPX, NPDA [NPIX, NPXI], NPVIII), and later Quitor Phase forms with marked everted rims (NPXIII, NPII, and late forms of NPIII with convex base and two horizontal handles; Tarragó 1989).

San Pedro ceramic types include an early set of wares (e.g., Los Morros, Loa Café Alisado; see Table 1) found in the high river canyons located on the descending plane of the Andes mountains to the southeast of San Pedro and at some habitational sites in the oases (Agüero and Uribe 2011; Núñez et al. 2006; Uribe 2006). This utilitarian ceramic tradition, comprising some regional differences, was shared by many contemporaneous communities throughout northern Chile and the south-central

Table 1. Ceramic Chronology, San Pedro de Atacama (northern Chile). Cronología cerámica, San Pedro de Atacama (norte de Chile).

\begin{tabular}{cccc}
\hline Dates & Period & Phase & Associated Ceramic Styles \\
\hline 1500-1200 BC & Transition to Formative & Tajane & Los Morros \\
1200-300 BC & Formative & Tilocalar & Los Morros, A \& B \\
300 BC-AD 100 & & Toconao & Loa Café y Rojo Alisados \\
AD 100-400 & & Rojuitor Pulido \\
& & Quitor & Negro Pulido (early variants) \\
AD 400-700 & Middle Period & Coyo & Negro Pulido (late variants) \\
AD 700-900 & & Incisos, Negro and Rojo \\
AD 900-1000 & Late Intermediate Period & Yaye-Solor & Gris Grueso Pulido \\
AD 1000-1300 & & Turi-Quitor & Gris Café Pulido \\
AD 1300-1450 & & Toconce-Zápar & Dupont Negro Pulido \\
& & & Rojo Violáceo \\
AD 1450-1550 & & Aiquina Café Rojizo \\
\end{tabular}

Sources: Agüero and Uribe 2011; Berenguer et al. 1986; 1988; Núñez et al. 2006; Tarragó 1989; Uribe 2002, 2006; Uribe and Ayala 2004. 
Andes (Ayala 2001; Núñez 2005; Uribe 2006, 2009; Uribe and Ayala 2004).

Subsequent mortuary ceramics in Formative and Middle Period San Pedro are highly standardized black or red burnished fine wares (Stovel 2005; see Figures 2 to 4 ). By approximately $300 \mathrm{BC}$, burnished red Rojo Pulido jars became popular in local graves. These are remarkably consistent in shape, found usually as tall necked jars with flared rims, with infrequent lug handles and/or anthropomorphic faces at the neck. This consistent shape is accompanied by high variation in size, color, and degree of external polish. Rojo Pulido vessels may have only been used in burials (Uribe 2006:470) but the variation in their surface coloring and the high variability in the colors of polished wares found in San Pedro houses prevent their confident identification in domestic contexts.

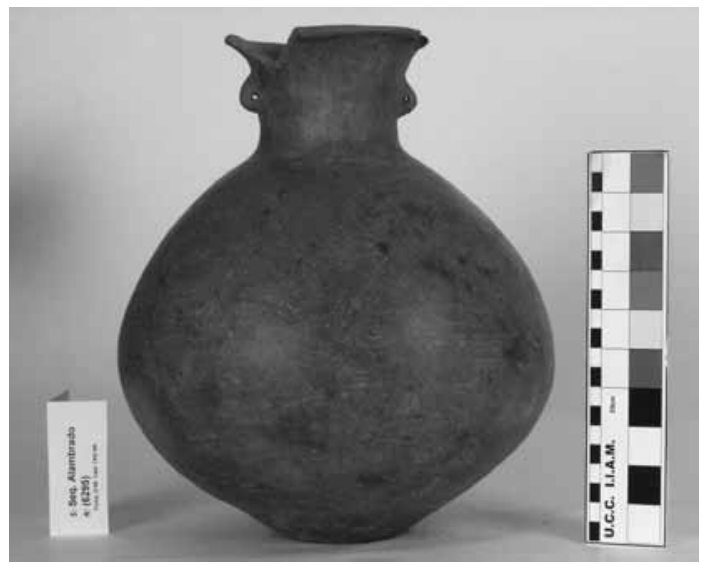

Figure 2. Rojo Pulido Ceramic Type. Photo used with the permission of the IIAM-UCN.

Tipo cerámico Rojo Pulido. Foto con el permiso del IIAM-UCN.

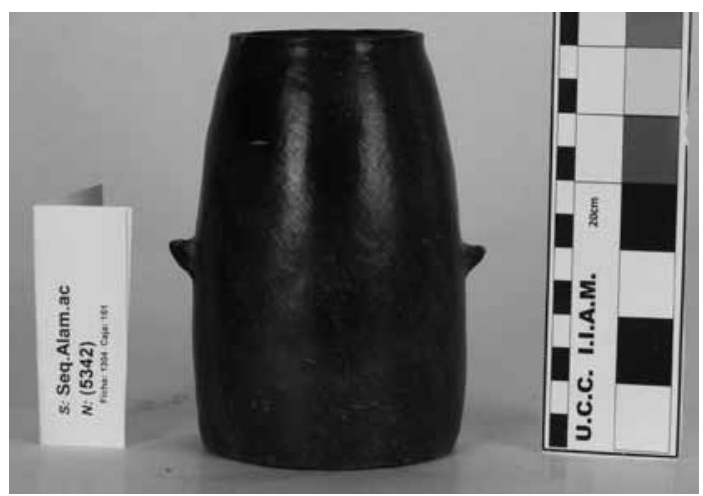

Figure 3. Negro Pulido Ceramic Type (shape class II). Photo used with the permission of the IIAM-UCN.

Tipo cerámico Negro Pulido (forma II). Foto con el permiso del IIAM-UCN.

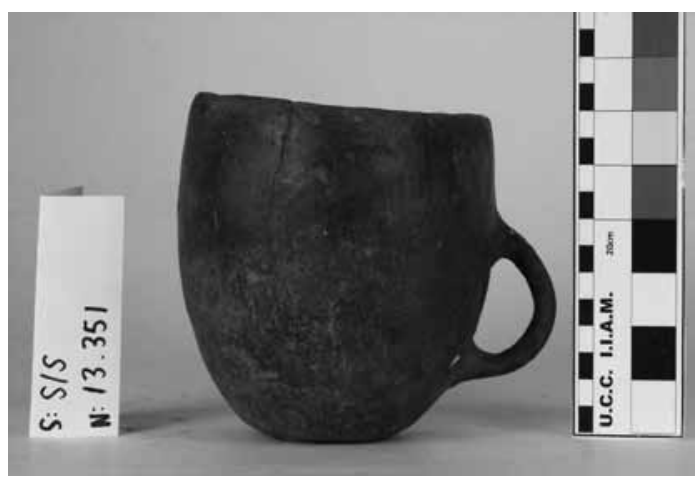

Figure 4. Gris Grueso Pulido Ceramic Type (shape class IpaV). Photo used with the permission of the IIAM-UCN.

Tipo cerámico Gris Grueso Pulido (forma IpaV). Foto con el permiso del IIAM-UCN.

Rojo Pulido (RP) jars are accompanied in burials by early forms of the Negro Pulido burnished blackware tradition, with straight rims and tall, straight vessel walls, and large smoothed utilitarian urns with conical bases (Tarragó 1989; Uribe 2006). Rojo Pulido jars are characteristic of the Toconao Phase (ca. 300 BC-AD 100), followed by late Formative Negro Pulido forms during the Sequitor Phase (ca. AD 100-400). These constitute the first wave of the famous monochromatic polished ceramics of San Pedro during the second half of the Formative Period, coinciding with a cultural consolidation in the oases, the expansion of agricultural production to include corn, and the development of complex mortuary rituals and some social differentiation.

The Middle Period (ca. AD 400-900) in San Pedro coincides with the appearance of Tiwanaku style material culture in local graves (Uribe and Agüero 2001, 2004). Although it is clear that San Pedro was not a colony of Tiwanaku (Torres-Rouff 2002, 2008), San Pedro residents clearly consumed objects with Tiwanaku iconography, possibly to enhance local power relations (Berenguer and Dauelsberg 1989; Stovel 2005; Torres and Conklin 1995; Torres-Rouff 2002). The display of this material culture in graves suggests that Tiwanaku practices and/or beliefs were least an important part of ritual life, which included the consumption of hallucinogenic powders (Llagostera 2006; Torres 1988, 2001). No Tiwanaku remains or Tiwanaku associated remains have been found so far in household contexts, although these remain poorly studied.

Local ceramic production is very refined in the first half of the Middle Period. Late Negro Pulido burial forms are thin-walled, highly burnished, very 
black, of compact, refined clay, and accompanied occasionally by red or black incised high-walled bowls. In contrast with earlier forms, they favor strongly everted rather than straight lips and restricted rather than unrestricted forms. During the second half of the Middle Period, burials contain fewer high quality pieces. Incised bowls and some late blackware forms continue to appear, but are accompanied or replaced by grey burnished vessels with thicker walls (GPG). Late Formative and Middle Period burials also contain black burnished anthropomorphic bottles. These are not found in household remains and display a change in bottle form through time and the abstraction of an anthropomorphic human face to four incised dots (Figure 5). Although other Middle Period Negro Pulido forms are found in household settings with much more variable surface color, anthropomorphic bottles are extremely rare in these contexts. The production and inclusion in tombs of abundant, refined ceramic vessels is very characteristic of Middle Period graves. There are marked differences in the access and display of large quantities of these vessels, and their rigorous adherence to aesthetic norms suggests they were produced for burial consumption.

The Late Intermediate Period (ca. AD 900-1450) has been characterized (Costa 1988; Tarragó 1989) as one of cultural impoverishment, lacking in burial material culture, possibly caused by the collapse of relations with the Tiwanaku polity (see also Torres-Rouff and Costa 2006; Torres-Rouff et al. 2005). Uribe (1997, 2002; see also Uribe and Adán 2005) has undertaken a complex reexamination of

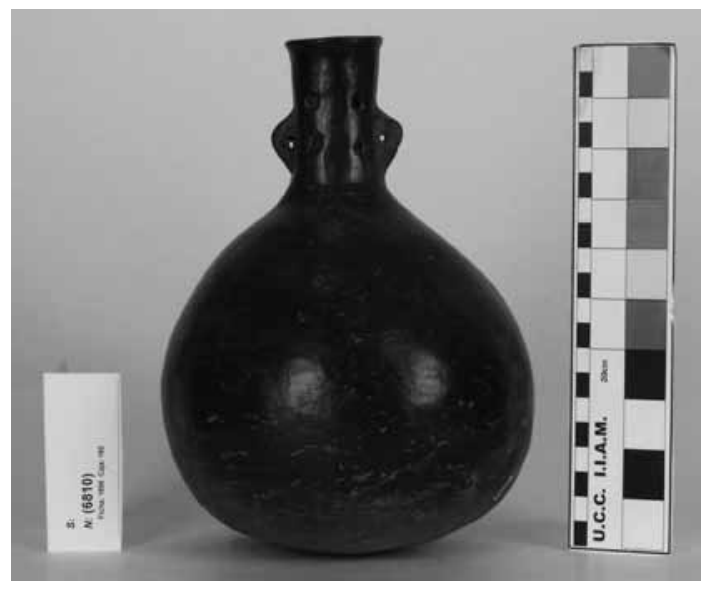

Figure 5. Anthropomorphic Bottle, decorated Negro Pulido type (face type B). Photo used with the permission of the IIAM-UCN. Botella antropomorfa tipo Negro Pulido Decorado (tipo cara $B)$. Foto con el permiso del IIAM-UCN. ceramic production in this area and the neighboring Alto Loa, proposing a two part ceramic sequence for the Late Intermediate Period (reflecting similar new understandings throughout the Andes; i.e. Arkush 2009; Covey 2008). The first half of the period is characterized by a decline in the frequency of ceramics found in local graves. Individuals are accompanied by gourd containers and basketry and domestic ceramics. Burial and household ceramics are more similar and are large open bowls with red or black burnished interior surfaces (Aiquina and Dupont styles respectively). These are accompanied by larger smoothed urns. The second half of the period is characterized by the construction of defensive sites (i.e., Quitor), increased presence of southern Bolivian material culture in domestic contexts (i.e., Zapar), an increase in red polished bowls with respect to the black ones, an increase in smaller red and brown jars originally identified in the LIP site of Turi in the Alto Loa (Figure 1), and again, large smoothed urns.

The Late Period, marked by Inka influence in the area, witnesses the production of local variants of Inka ceramic forms and the continuation of local LIP styles, including Aiquina and Brown and red Turi variants (polished and smoothed) (Uribe 2004; Uribe et al. 2002). Immediately prior to the arrival of the Spaniards in the area, local potters in San Pedro and the Alto Loa begin producing ceramics with abundant mica in their pastes, a tradition that continues today (Uribe and Carrasco 1999). Micaceous ceramics are sold today in local fairs. This time period was not examined by Berenguer and colleagues.

This ceramic sequence has obviously functioned well for more than 20 years. There are some complexities, however, that warrant consideration here. The more we study household ceramics, for example, the more accepted styles appear to be the result of dedicated ritual production. Household ceramics are more variable in their color and adherence to the aesthetic norms found with burial vessels, but less variable in the range of forms (Sinclaire et al. 1997). The identification of Rojo Pulido ceramics in household contexts is complicated by the high degree of color variation in domestic finewares in general, and of Rojo Pulido jars specifically. If both red and black polished wares were exclusively ritual in their use, then perhaps we are not facing chronologically sequential types, but styles with different social meanings. 
Gris Grueso Pulido (GPG) is also a difficult category. It was originally identified by Tarragó (1989) as having an early experimental presence (i.e., "almost" blackware) and a later degraded post-Tiwanaku time (i.e., degraded echo of past glory), but Berenguer et al. $(1986 ; 1988)$ queried the existence of this type. A look at household remains suggests that some iterations of Negro Pulido are highly variable in surface color and treatment and although some Gris Pulido Grueso forms may be more frequent after the Middle Period, they may also be contemporaneous with Negro Pulido, reflecting normal shape and color variation within the stylistic and production gradient of domestic Negro Pulido only occasionally included in graves. In fact, Tarragó (1989:371) collapses important Late Intermediate Period styles Dupont and Aiquina into this ceramic class, which, according to Uribe (2002), have their own chronological (and phase defining) differences. As such, the Gris Pulido Grueso category is problematic and should be used with caution.

Additionally, many of the 40 TL dates Berenguer et al. $(1986 ; 1988)$ provide to bolster Tarragó's research were carried out on pots from Toconao Oriente, a site located $40 \mathrm{~km}$ from the oases of San Pedro, which may reflect a slightly different cultural history and chronological sequence. Two Toconao Oriente dates provided in one of Hubbe and Torres-Rouff's (2011) papers were not used for the present study. Finally, the late Rojo Violáceo style turns out to be a rare ceramic type, ill-suited to serve as a marker of the Late Intermediate Period, which is better understood through the aforementioned Dupont and Aiquina bowls, in conjunction with Turi variants defined after Tarragó's seminal work (Varela et al. 1993). These problems suggest the ceramic sequence in San Pedro warrants reexamination; bringing together the loose ends of research conducted since Tarragó's work will show whether new discoveries present inconsistencies or confirm accepted sequences and how. The present study reviews the key diagnostic ceramic types for the area and their chronologies in light of new AMS dates obtained from human remains (Hubbe and Torres-Rouff 2011; Hubbe et al. 2011).

\section{New Absolute Dates and Research Methods}

A new set of 48 AMS dates (see Table 2; Hubbe and Torres-Rouff 2011; Hubbe et al. 2011) were obtained from the organic fraction (collagen) of human cranial remains from collections housed at the Instituto de Investigación Arqueológica y Museo Gustavo Le Paige in San Pedro de Atacama. All dates were calibrated using the SHCAL4 curve within the Calib 6.0 program and are given as both absolute dates (AP) and calendrical dates calibrated with 2 sigma as outlined in the original publications (Hubbe and Torres-Rouff 2011; Hubbe et al. 2011). These new dates allow the authors to reexamine the prehistoric occupation of the oases during the late Formative expanding to northern sites by the end of the Middle Period (ca. AD 1000; Hubbe and Torres-Rouff 2011:259-260). These results are echoed by Llagostera and Costa (1999) and Agüero and Uribe (2011:76). In her 2005 survey, Carolina Agüero documents an even earlier occupation and expansion from the southern ayllus during the middle Formative (see also Núñez 2005).

This is a pivotal moment in San Pedro prehistory. Over the late Formative we see a consolidation of sedentary communities in the oases and the development of agricultural practices along with complex burial ceramic production. These communities are perhaps trading copper ores (i.e., turquoise and malachite) of symbolic importance (Agüero and Uribe 2011) though some debate remains concerning the beginnings of local metallurgical activities (Salazar et al. 2011). Some absolute dating is presented in support of ceramic characterization of site chronology in surveys that sustain our understanding of this key period (Agüero and Uribe 2011; Núñez 2005), but Llagostera and Costa (1999) and Agüero (2005) also base their regional surveys on ceramic differences. Ceramic chronology, therefore, is an important piece in the narrative of late Formative social changes on the eve of contact with Tiwanaku traders and can only benefit from testing with a set of additional AMS dates, although more dates from household contexts remain an urgent need.

In order to begin to answer these questions, the list of dates was combined with ceramic information from Le Paige's unpublished excavation notes and summarized in Table 2. Of the original forty eight published dates ${ }^{1}$, twenty three held information about ceramics that permitted their classification with known local styles. Seven of these were associated with utilitarian ceramics that were not illustrated, one with nonlocal ceramics, and therefore fifteen remained with identifiable black or red polished vessels. Eight of the forty 


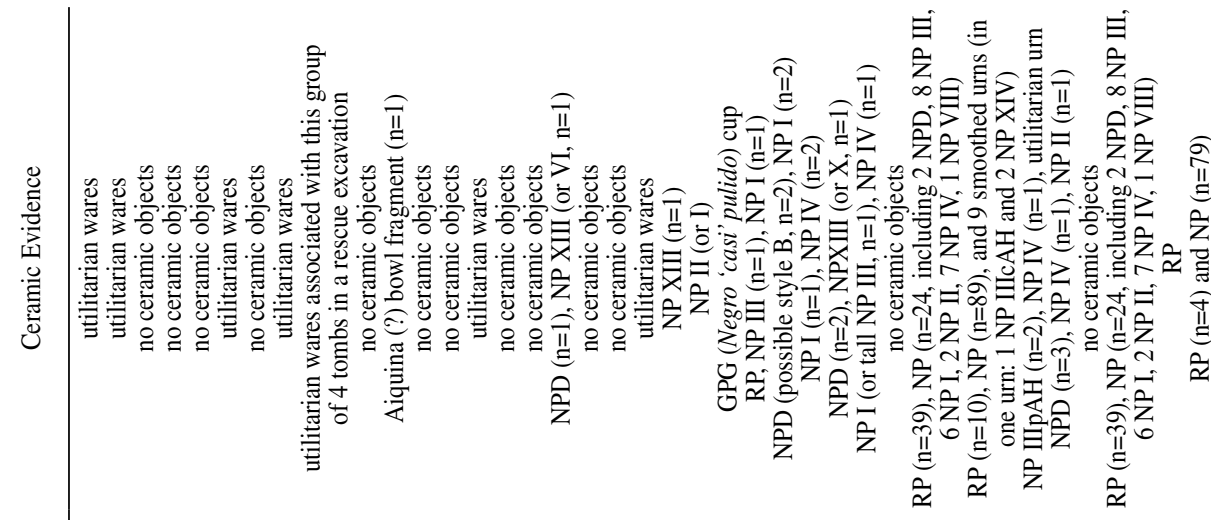

इ

की 11 छ

il

北之京

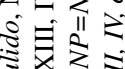

₹ $\bar{x}=$

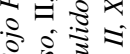

काँ

ते जे

क्ष

ज次

है

ن

च

㝖

물

商

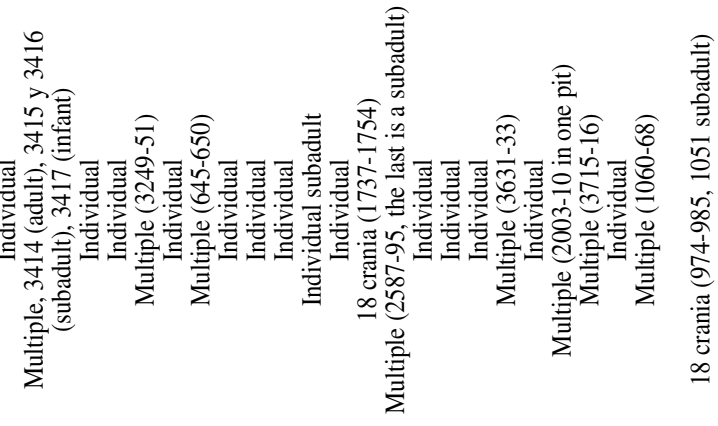

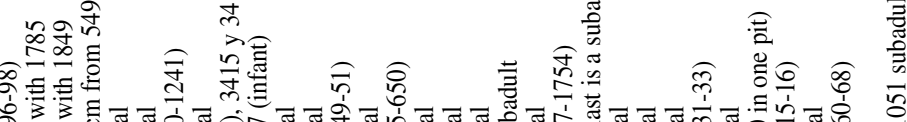

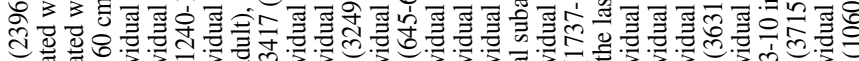

等

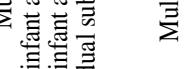

尊

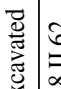

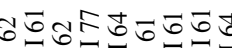

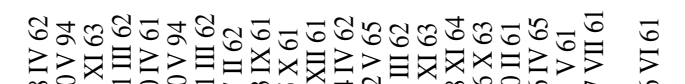

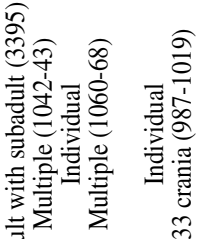

저슨

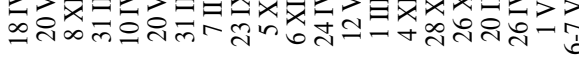

‥

$2 \stackrel{0}{=}$

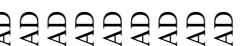

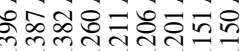

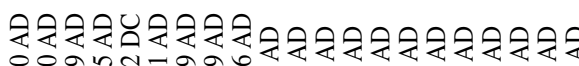
는의

में

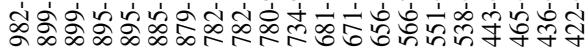

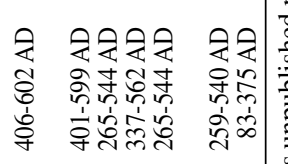
चี

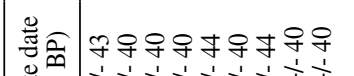

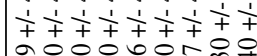

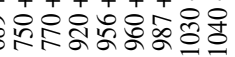

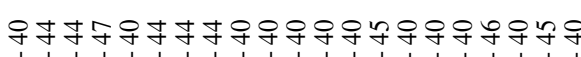

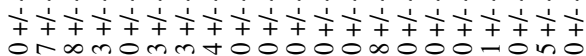

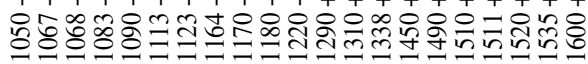


eight dates pertained to tombs detailed in Tarragó's (1989) sample and thus further specification as to ceramic type was possible in these cases. Twelve tomb contexts that did not contain ceramic objects also appear in Table 2 where all dates are ordered from most recent to oldest.

\section{Revisions to San Pedro Ceramic Chronology?}

Table 2 confirms that Negro Pulido was the characteristic ceramic style of the Middle Period. Quitor Phase (ca. AD 500-700) Negro Pulido forms (NP II, NP XIII, and NPDB), however, are associated with human remains with dates from throughout the late Formative and Middle Periods. Rojo Pulido dates from this data set range from just before $\mathrm{AD}$ 100 to halfway through the Middle Period (ca. AD 600 -700). Red and black wares are therefore generally sequential in time, but contexts that would have previously been placed in the Toconao Phase (300 BC to AD 100) because of the presence of Rojo Pulido (e.g., Agüero and Uribe 2011:70) might equally date to Sequitor and Quitor Phases (AD 100-700). The Quitor 2 tomb with only Rojo Pulido is contemporaneous with graves with Rojo Pulido and Negro Pulido (Tomb 1068, Sequitor Alambrado) and Negro Pulido alone (Tomb 1043, Sequitor Alambrado). Figure 6 provides a graphic picture of the new dates, demonstrating that all Rojo Pulido graves studied here postdate their putative period of popularity, the Toconao Phase. Rojo Pulido graves (most of which also contain Negro Pulido vessels) are contemporaneous with many graves containing only Negro Pulido vessels. Significantly, Rojo Pulido graves are contemporaneous with late, Quitor Phase, forms of Negro Pulido. Contexts with Rojo Pulido vessels clearly date to later time periods than previously thought.

Tarragó (1989:381) found in her sample that tombs with only Rojo Pulido were much less frequent than those with both Rojo and Negro Pulido, which in turn were much less frequent than those with Negro Pulido alone. The paucity of tombs with Rojo Pulido alone in the current sample does not let us explore this as a burial practice, but the contemporaneity of combined Rojo and Negro Pulido graves with only Negro Pulido vessels suggests that we may be facing two concurrent types of graves rather than chronologically sequential practices. In 1985 Mario Orellana asserted, although in reference to tombs found in neighboring Toconao (see note 1), that
Phase I (pre-AD 200) was likely characterized by San Pedro Rojo Pulido in combination with other ceramic types, including Negro Pulido.

Table 2 also provides another date range for a single Gris Grueso Pulido cup: AD 656-865. Previous dates for similar forms were AD $580 \pm 11$ and $710 \pm 110$ (Berenguer et al. 1986; 1988; Tarragó 1989:62). These dates are well within the Middle Period and do not suggest that these vessels represent a decline in Negro Pulido ceramic perfection. Its contemporaneity with other ceramic practices suggests stylistic differences with other causes; these may be household items included in graves that do not share burial norms of thin-walled, highly burnished vessels.

Utilitarian wares date predominantly to the later Middle Period and Late Intermediate Period (LIP), while graves without ceramic objects, although providing dates from the late Formative through the Late Intermediate Periods, cluster around the end of the Middle Period and first phases of the LIP. The LIP was originally seen as a moment of cultural impoverishment caused by the decline in Tiwanaku influence ca. $900 \mathrm{AD}$ (Costa 1988; see Uribe et al. 2004 for a divergent view) but more likely reflects a shift in burial practices where elaborate ritual goods are replaced with more mundane domestic goods and ceramic pots are replaced with decorated gourds and baskets.

How does this compare with results from the regional surveys mentioned previously? To begin, residential sites should not be dated using evidence of Rojo Pulido if these are exclusively burial vessels and fragmented remains of household variants of Negro Pulido (i.e., Café Pulido, Sinclaire et al. 1997) that resemble Rojo Pulido. Rojo Pulido tombs from the sample considered here clearly date to Sequitor and Quitor Phases should cause household archaeologists to pause before using this type as a chronological marker. Sites with these remains would be erroneously restricted to the earlier Toconao Phase. If we use burial data to organize household remains, which we must do until household ceramic production is better understood, the ceramic evidence presented here suggests regional surveys might have overestimated the quantity and date of early sites.

All the same, Rojo Pulido is common in multiple burials ranging from thirty three to two individuals. Of the five tombs with Rojo Pulido vessels in the present sample, two are graves of individuals and three hold multiple individuals. This 


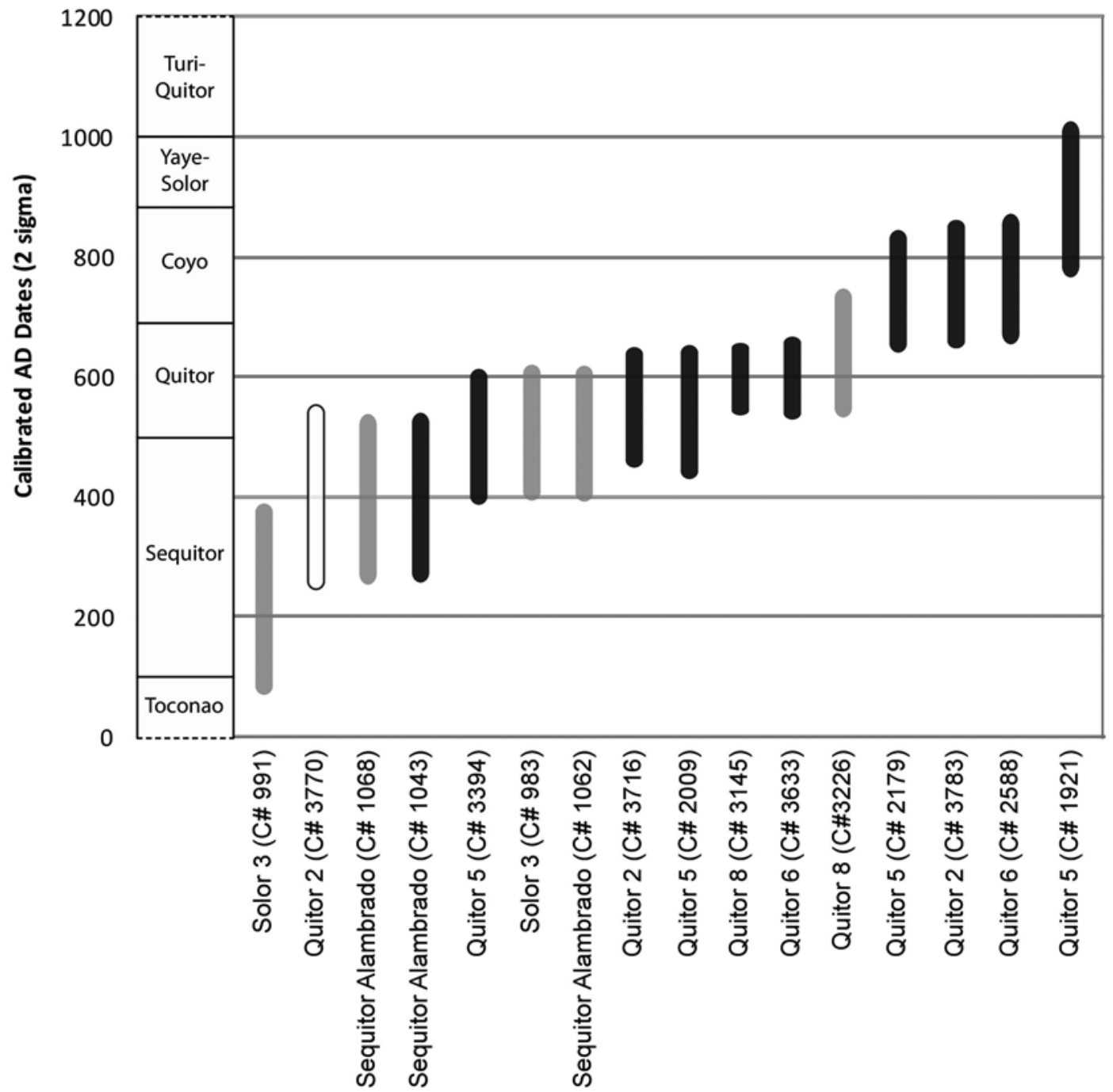

Figure 6. C14 Dates of ceramic combinations found in tombs. Transparent $=$ Rojo Pulido alone, Grey $=$ Rojo Pulido and Negro Pulido, Black = Negro Pulido alone (Sources: Hubbe and Torres-Rouff 2011; Hubbe et al. 2011; Le Paige's unpublished manuscripts; Tarragó 1989; Uribe and Adán 2005).

Fechas RC14 para combinaciones cerámicas encontradas en tumbas. Transparente $=$ Rojo Pulido sólo, Gris claro $=$ Rojo Pulido y Negro Pulido, Negro = Negro Pulido sólo (Fuentes: Hubbe y Torres-Rouff 2011; Hubbe et al. 2011; notas inéditas de Le Paige; Tarragó 1989; Uribe y Adán 2005).

may be caused by placing individuals into graves with earlier individuals and vessels. Perhaps Rojo Pulido was more common in building multiple burials (although there are also multiple burials with Negro Pulido alone). Father Le Paige is very clear in his notes, however, that multiple burials are associated with specific ranges of materials. If multiple burials do constitute somewhat "closed finds", it would appear that Rojo Pulido and Negro Pulido are more contemporaneous than previously thought. We see the development of a burial practice employing Negro Pulido vessels alone during the second half of the Middle Period after a long period of joint burial of red and black wares. This may reflect changes in burial beliefs and rituals that need to be examined within each cemetery, but the difference between these two wares may not be chronological. Larger studies must challenge the results presented here with more absolute dates and contextualized tomb sets. 
That said, these results were foreshadowed in previous research, but deemed anomalous and discarded. Tarragó (1989) mentions 3 cases of Rojo Pulido ceramic associated with Negro Pulido, large utilitarian vessels and Tiwanaku objects (association class 4.5). Berenguer and colleagues' (1986; 1988) TL dates also reveal a few later dates for contexts with Rojo Pulido vessels (see Table 3), but the authors eliminated those inconsistencies in order to present more discrete chronological phases. They changed the earliest date of the phase to pull it back from a smoothed urn (often found in combination with fine wares throughout San Pedro burial history) and the later date in order to not include a range of Negro Pulido vessels presumed to be later in date. The authors recognized the complexity of this process:

\section{Nuestro rango cronológico estimativo para esta fase [Toconao] es 300 a.C. a 100 d.C. La fecha inicial la hemos hecho algo más reciente de lo que indica la más temprana de sus fechas, por su cercanía a la fecha [previa] de la urna. La fecha final, en cambio, se basa en los datos de superposición estratigráfica entre las fechas $N^{o} 9$ y 10. En este entendido, entonces, habría que incorporar a esta fase a todas aquellas cerámicas o asociaciones cerámi- cas fechadas dentro de dicho rango $\left(N^{o} 3\right.$, 4, 6 y 8). Esta reubicación, sin embargo, plantea el primer problema serio con la secuencia de Tarragó, y que las fechas $3 y$ 8 corresponden a la asociación 4, atribuida a la fase III (Berenguer et al. 1986:40-41).}

Although it is justifiable to disregard a single anomalous date, this problem can also be caused by assuming that association classes and ceramic ware types are ordered sequentially in time in a linear fashion.

\section{Implications for Current and Future Research in the Area}

Certainly our understanding of a late Formative cultural fluorescence in San Pedro is strongly affected by these results. Rather than temporally sequential, ceramic production diversity may have characterized the entire late Formative and Middle Period. The restriction in shape types for Rojo Pulido may be a product of its use functions, sacred and profane, rather than representing an exploratory phase of San Pedro ceramic development. We may be confronting the production of a series of relatively contemporaneous ceramic styles rather than a temporal sequence from red to black and then grey.

Acceptance of Torres-Rouff and Hubbe's C14 dates in conjunction with Berenguer et al.'s TL dates implies understanding that Rojo and Negro Pulido are both late Formative and Middle Period ceramic types, changing significantly our understanding of regional settlement surveys which use ceramics as chronological markers. While there appears to be a slight temporal sequence between Rojo and Negro Pulido wares (graves with Rojo Pulido vessels are more likely to provide an earlier date than those with later Negro Pulido forms and early forms are more likely to combine with Rojo Pulido) these forms and wares previously thought to have occurred sequentially in time might have been contemporaneous. In addition, most of the ceramic styles studied here accompanied human remains that dated to the Middle Period. It is possible that Middle Period people were buried with late Formative vessels, because the $\mathrm{C} 14$ dates were established from skeletal material and the TL dates were conducted on the vessels themselves. But the fact that this chronological shift occurs predominantly in the case of Rojo Pulido (for which we also have late TL dates) suggests that these new $\mathrm{C} 14$ dates are likely to be accurate for these vessels too. It is likely that we are facing two discrete practices involving mortuary ceramic consumption: those individuals buried with Rojo and Negro Pulido vessels, and those buried with Negro Pulido vessels alone. These differences require consideration with respect to other axes of social difference: wealth, power, community membership, gender, age difference, etc.

Previous chronological phases in San Pedro were based on a complex and thorough classification of material culture, stratigraphic superposition, association with known nonlocal material culture, and absolute dates. But the assumption of chronologically sequential cemeteries and ceramic styles caused adjustments to be made that have not been borne out by more recent information. As this sequence was based on a reduced number of absolute dates and sporadic subsequent dating events, the contemporaneity of these Rojo and Negro Pulido styles was not revealed. It remains to be seen if this coexistence is confirmed by future research and 
Table 3. TL Dates and Associated Ceramic Types.

Fechas TL y tipos cerámicos asociados.

\begin{tabular}{|c|c|c|}
\hline Ceramic Type & Shape Classes & TL Dates \\
\hline \multirow[t]{3}{*}{ Rojo Pulido } & $\mathrm{IpaV}$ & $170 \pm 180 \mathrm{BC} / \mathrm{AD} 150 \pm 150$ \\
\hline & & $40 \pm 170 \mathrm{BC} / \mathrm{AD} 220 \pm 130$ \\
\hline & & $\mathrm{AD} 90 \pm 200 / \mathrm{AD} 240 \pm 140$ \\
\hline \multirow[t]{15}{*}{ Negro Pulido } & $\mathrm{IpaV}$ & AD $90 \pm 220$ \\
\hline & IpAH & AD $230 \pm 160$ \\
\hline & & $\mathrm{AD} 240 \pm 140$ \\
\hline & II & AD $720 \pm 95$ \\
\hline & III & $\mathrm{AD} 140 \pm 150 / \mathrm{AD} 230 \pm 160$ \\
\hline & & $\mathrm{AD} 150 \pm 115 / \mathrm{AD} 255 \pm 120$ \\
\hline & & $\mathrm{AD} 220 \pm 130 / \mathrm{AD} 325 \pm 190$ \\
\hline & IV & AD $220 \pm 130$ \\
\hline & & $\mathrm{AD} 440 \pm 100$ \\
\hline & & $\mathrm{AD} 620 \pm 100$ \\
\hline & VII & $\mathrm{AD} 510 \pm 150$ \\
\hline & VIII & $\mathrm{AD} 350 \pm 130$ \\
\hline & XII & AD 720 \pm 95 \\
\hline & XIII & $\mathrm{AD} 620 \pm 199$ \\
\hline & & $\mathrm{AD} 660 \pm 130$ \\
\hline \multirow[t]{6}{*}{ Negro Pulido Decorado } & A & $40+170 \mathrm{BC}(\mathrm{RP})$ \\
\hline & & AD 160+180 (XIoAH) \\
\hline & $\mathrm{AB}$ & AD 310+160(XIIc) \\
\hline & $\mathrm{B}$ & AD 720+95 (XIIcM) \\
\hline & & AD 720+120(XIIcM) \\
\hline & & AD 340+125 (anomalous?) \\
\hline \multirow[t]{2}{*}{ Inciso } & NGR & AD $720+95$ \\
\hline & RGR & AD $580+140$ \\
\hline \multirow[t]{8}{*}{ Gris Grueso Pulido } & $\mathrm{IpaV}$ & AD $580+110$ \\
\hline & & AD $710+110$ \\
\hline & IXc & AD $720+130$ \\
\hline & IVc & AD $850+110$ (Aiquina) AD $1140+70$ \\
\hline & & AD $920+120 /$ AD $1185+70$ (Dupont) \\
\hline & & AD $940+130$ (Aiquina) \\
\hline & Io & $350+235 \mathrm{BC}$ \\
\hline & IcLV & AD $120+140$ \\
\hline
\end{tabular}

Sources: Berenguer et al. 1986; 1988; Tarragó 1989.

if so, to explain its social origins. In particular we need to clarify the domestic presence or absence of Rojo Pulido ceramics and take care when we assign contexts containing this style to the Toconao Phase. In addition we must take care with the Gris Grueso Pulido category as originally conceived by Tarragó (1989), as our current understanding of variation in finewares from domestic and mortuary contexts may lead to its abandonment. We need to focus on testing the chronological value of currently accepted shape classes and tackle the category of Gris Grueso Pulido through a systematic identification of pieces and the comparison of household and burial samples. To be sure, domestic ceramic analysis is a vital next step in San Pedro archaeology, not only for chronological concerns, but for a more complex and complete understanding of local prehistoric life.

Acknowledgements: This work was carried out as part of the Anillos Project ACT96 (www. cienciaymemoria.cl) supported by the Chilean Research Foundation, CONICYT. It is also indebted to Christina Torres-Rouff, Mark Hubbe, William Whitehead, Amanda McConnell, and functionaries of the Instituto de Investigación Arqueológica y Museo Gustavo Le Paige. I am thankful for to the support of the Dumbarton Oaks Research Library staff for the completion of this manuscript. Finally, careful examination of this paper by reviewers led to many improvements, for which I am also grateful. 


\section{References Cited}

Agüero, C. 2005. Aproximación al asentamiento humano temprano en los oasis de San Pedro de Atacama. Estudios Atacameños 30:29-60.

Agüero, C., and M. Uribe 2011. Las sociedades formativas de San Pedro de Atacama: Asentamiento, cronología y proceso. Estudios Atacameños 42:53-78.

Arkush, E. 2009. Pukaras de los collas: guerra y poder regional en la cuenca norte del Titicaca durante el Período Intermedio Tardío. Andes 7:463-479.

Ashley, C.Z. 2010. Towards a socialised archaeology of ceramics in great lakes Africa. African Archaeological Review 27:135-163.

Ayala, P. 2001. Las sociedades formativas del altiplano circumtiticaca y meridional y su relación con el norte grande de Chile. Estudios Atacameños 21:7-39.

Berenguer, J. 1978. La problemática Tiwanaku en Chile: visión retrospectiva. Revista Chilena de Antropología 1:17-40.

- _ _ 1998. La iconografía del poder en Tiwanaku y su rol en la integración de zonas de frontera. Boletín del Museo Chileno de Arte Precolombino 7:19-37.

- _ _ 2000. Tiwanaku. Señores del Lago Sagrado. Museo Chileno de Arte Precolombino, Santiago.

- _ _ 2004. Caravanas, Interacción y Cambio en el Desierto de Atacama. Sirawi Ediciones, Santiago.

Berenguer, J., and P. Dauelsberg 1989. El Norte Grande en la órbita de Tiwanaku. In Culturas de Chile. Prehistoria: Desde sus Orígenes hasta los Albores de la Conquista, edited by J. Hidalgo, V. Schiappacasse, H. Niemeyer, C. Aldunate, and I. Solimano, pp. 129-180. Ed. Andres Bello, Santiago.

Berenguer, J., V. Castro, and O. Silva 1980. Reflexiones acerca de la presencia de Tiwanaku en el norte de Chile. Estudios Arqueológicos 5:81-93.

Berenguer, J., A. Deza, A. Roman, and A. Llagostera 1986. La secuencia de Myriam Tarragó para San Pedro de Atacama: Un test por termoluminiscencia. Revista Chilena de Antropología 5:17-54.

Berenguer, J., A. Roman, A. Deza, and A. Llagostera 1988. Testing a cultural sequence for the Atacama Desert. Current Anthropology 29:341-346.

Beresford-Jones, D., H. Lewis, and S. Boreham 2009. Linking cultural and environmental change in Peruvian prehistory: Geomorphological survey of the Samaca Basin, Lower Ica Valley, Peru. Catena 78(3):234-249.

Bravo, L., and A. Llagostera 1986. Solcor 3: Un aporte al conocimiento de la Cultura San Pedro. Período 500 al 900 d.C. Chungara 16-17:323-332.

Buck, C.E., and S.K. Sahu 2000. Bayesian models for relative archaeological chronology building. Journal of the Royal Statistical Society: Series C (Applied Statistics) 49(4):423-440.

Costa, M.A. 1988. Reconstitución física y cultural de la población tardía del cementerio de Quitor-6 (San Pedro de Atacama). Estudios Atacameños 9:99-126.
Costa, M.A., and A. Llagostera 1994. Coyo-3: Momentos finales del Período Medio en San Pedro de Atacama. Estudios Atacameños 11:73-107.

Costa, M.A., W. Alves Neves, and M. Hubbe 2004. Influencia de Tiwanaku en la calidad de vida biológica de la población prehistórica de San Pedro de Atacama. Estudios Atacameños 27:103-116.

Covey, R.A. 2008. Multiregional perspectives on the archaeology of the Andes during the Late Intermediate Period (c. AD 1000-1400). Journal of Archaeological Research 16:287-338.

Crombé, P., J. Sergant, L. Lombaert, M. Van Strydonck, and M. Boudin 2009. The Mesolithic and Neolithic site of VerrebroekAven Ackers (East Flanders, Belgium): The radiocarbon evidence. Notae Praehistoricae 29:15-21.

Crombé, P., M. Van Strydonck, J. Sergant, M. Boudin, M. Bats, and M. van Strydonck 2009. Towards a refinement of the absolute (typo) chronology for the early Mesolithic in the Coversand area of northern Belgium and the southern Netherlands. In Proceedings of the International Congress "Chronology and Evolution in the Mesolithic of North-Western Europe", edited by P. Crombé, M. Van Strydonck, J. Sergant, M. Boudin, and M. Bats, pp. 95-112. Cambridge Scholars Publishing, Cambridge.

De Mulder, G., W. Leclercq, and M. Van Strydonck 2008. Influence from the 'groupe Rhin-Suisse-France Orientale' on the pottery from the late Bronze Age urnfields in Western Belgium. A confrontation between pottery building technology, ${ }^{14} \mathrm{C}$-dates, and typo-chronology. In Breaking the Mould: Challenging the Past through Pottery, edited by I. Berg, pp. 105-115. Prehistoric Ceramics Research Group: Occasional Paper 6. BAR International Series 1861. Archaeopress, Oxford.

Duff, A.I. 1996. Ceramic micro-seriation: Types or attributes? American Antiquity 61:89-101.

Dunnell, R.C. 1970. Seriation method and its evaluation. American Antiquity 35:305-319.

Finkelstein, I., and E. Piasetzky 2010. Radiocarbon dating the Iron Age in the Levant: a Bayesian model for six ceramic phases and six transitions. Antiquity 84:374-85.

Goldstein, P. S. 2005. Andean diaspora: the Tiwanaku colonies and the origins of South American empire. University Press of Florida, Gainesville.

Gundermann, H. 2004. Inicios de siglo en San Pedro de Atacama: Procesos, actores e imaginarios en una localidad andina. Chungara Revista de Antropología Chilena 36:221-239.

Hubbe, M., and C. Torres-Rouff 2011. Avances en la contextualización cronológica de la ocupación humana de los oasis atacameños. In Temporalidad, Interacción y Dinamismo Cultural: La Búsqueda del Hombre, edited by A. Hubert, J.A. González and M. Pereira, pp. 247-268. Universidad Católica del Norte, Ediciones Universitarias, Antofagasta.

Hubbe, M., M. Oviedo, and C. Torres-Rouff 2011. El estado de conservación de la colección osteológica Gustavo Le Paige y su contextualización cronológica. Estudios Atacameños 41:29-44. 
Knudson, K.J. 2007. La influencia de Tiwanaku en San Pedro de Atacama: Una investigación utilizando el análisis de isótopos del estroncio. Estudios Atacameños 33:7-24.

- _. _ 2008. Tiwanaku influence in the South Central Andes: strontium isotope analysis and Middle Horizon migration. Latin American Antiquity 19:3-23.

Kroeber, A.L. 1916. Zuñi potsherds. Anthropological Papers of the American Museum of natural History 18:7-37.

Le Paige, G. 1963. Continuidad y discontinuidad de la cultura atacameña. Anales de la Universidad del Norte 2:7-25.

. _ _ 1964. El precerámico en la cordillera atacameña y los cementerios del período agroalfarero en San Pedro de Atacama. Anales de la Universidad del Norte 3:49-93.

- _ _ 1966. Cráneos atacameños: evolución, ritos. Anales de la Universidad del Norte 5:5-82.

Le Paige, G., and C. Larraín 1961. Estudio craneométrico de la colección del museo de San Pedro de Atacama. Anales de la Universidad del Norte 1:1-48.

Lechtman, H.N., and A.W. MacFarlane 2005. La metalurgia del bronce en los Andes sur centrales: Tiwanaku y San Pedro de Atacama. Estudios Atacameños 30:7-27.

Llagostera, A. 2006. Contextualización e iconografía de las tabletas psicotrópicas Tiwanaku de San Pedro de Atacama. Chungara Revista de Antropología Chilena 38:83-111.

Llagostera, A., and M.A. Costa 1999. Patrones de asentamiento en la época agroalfarera de San Pedro de Atacama (norte de Chile). Estudios Atacameños 17:175-206.

Lyman, R.L., S. Wolverton, and M.J. O’Brien 1998. Seriation, superposition, and interdigitation: A history of Americanist graphic depictions of culture change. American Antiquity 63:239-261.

Müller, J. 2009. Dating the Neolithic: Methodological Premises and Absolute Chronology. Radiocarbon 51:721.

Nielsen, A.E., J. Berenguer, and C. Sanhueza 2006. El Qhapaqñan entre Atacama y Lípez. Intersecciones en Antropología 7:217-234.

Núñez, L. 1965. Desarrollo cultural prehispánico en el norte de Chile. Estudios Arqueológicos 1:37-115.

_ _ _ 1976. Registro regional de fechas radiocarbónicas en el norte de Chile. Estudios Atacameños 4:74-123.

. _ _ 2005. La naturaleza de la expansión aldeana durante el Formativo Tardío en la cuenca de Atacama. Chungara Revista de Antropología Chilena 37:165-193.

Núñez, L., and T. Dillehay 1995. Movilidad Giratoria, Armonía Social y Desarrollo en los Andes Meridionales. Patrones de Tráfico e Interacción Económica. Universidad Católica del Norte, Antofagasta.

Núñez, L., I. Cartajena, C. Carrasco, P. de Souza, and M. Grosjean 2006. Emergencia de comunidades pastoralistas formativas en el sureste de la puna de Atacama. Estudios Atacameños 32:93-117.

Oakland Rodman, A. 1992. Textiles and ethnicity: Tiwanaku in San Pedro de Atacama, North Chile. Latin American Antiquity 3:316-340

Olivier, L. 1999. The Hochdorf 'princely'grave and the question of the nature of archaeological funerary assemblages. In Time and Archaeology, edited by T. Murray, pp. 109-138. Routledge London.
Orellana, M. 1963. La cultura de San Pedro. Arqueología Chilena 3:3-43.

_ _ _ 1964 Acerca de la cronología del complejo cultural de San Pedro de Atacama. Antropología 2:96-104.

_ _ _ 1985. Relaciones culturales entre Tiwanaku y San Pedro de Atacama. Diálogo Andino 4:247-257.

Petrie Flinders, W.M. 1899. Sequences in prehistoric remains. The Journal of the Anthropological Institute of Great Britain and Ireland 29(3/4):295-301.

Renfrew, C. 1973. Before Civilization: The Radiocarbon Revolution and Prehistoric Europe. J. Cape, London.

Rice, P.M. 1987. Pottery Analysis: A Sourcebook. University of Chicago Press, Chicago.

Salazar, D., V. Figueroa, D. Morata, B. Mille, G. Manríquez, and A. Cifuentes 2011. Metalurgia en San Pedro de Atacama durante el Período Medio: nuevos datos, nuevas preguntas. Revista Chilena de Antropología 23:123-148.

Sinclaire, C. 1985. Dos fechas radiocarbónicas del Alero Chulqui, Río Toconce: noticia y comentario. Chungara 14:71-79.

Sinclaire, C., M. Uribe, P. Ayala, and J. González 1997. La alfarería del Período Formativo en la región del Loa Superior: sistematización y tipología. Actas del XIV Congreso Nacional de Arqueología Chilena. Contribuciones Arqueológicas 5:285-314.

Stanish, C. 2003. Ancient Titicaca: The Evolution of Complex Society in Southern Peru and Northern Bolivia. University of California Press, Berkeley.

Stanish, C., E. Vega, M. Moseley, P.R. Williams, C. Chávez J., B. Vining, and K. LaFavre 2010. Tiwanaku trade patterns in southern Peru. Journal of Anthropological Archaeology 29:524-532.

Steponaitis, V.P. 1983. Ceramics, Chronology, and Community Patterns: An Archaeological Study at Moundville. University of Alabama Press, Tuscaloosa.

Stovel, E.M. 2005. The Archaeology of identity construction: ceramic evidence from Northern Chile. In Global Archaeological Theory: Contextual Voices and Contemporary Thoughts, edited by P. Funari, A. Zarankin, and E, Stovel, pp. 145-166. Springer/ Kluwer, New York.

Tarragó, M. 1976. Alfarería típica de San Pedro de Atacama (norte de Chile). Estudios Atacameños 4:37-64.

_ _ _ 1989. Contribución al Conocimiento Arqueológico de las Poblaciones de los Oasis de San Pedro de Atacama en Relación con los Otros Pueblos Puneños, en Especial el Sector Septentrional del Valle de Calchaquí. Doctoral Dissertation, Universidad Nacional del Rosario, Argentina.

Téllez, F. and M. Murphy 2007. El cementerio Casa Parroquial; un rescate afortunado. San Pedro de Atacama, Chile. In Metalurgia en la América Antigua. Teoría, Arqueología, Simbología y Tecnología de los Metales Prehispánicos, edited by R. Lleras, pp. 53-82. Fundación de Investigaciones Arqueológicas Nacionales, Banco de la República de Colombia, Instituto Francés de Estudios Andinos, Bogotá.

Thomas, C., C. Massone, and M.A. Benavente 1984 Sistematización de la alfarería del área de San Pedro de Atacama. Revista Chilena de Antropología 4:49-119.

Torres, C.M. 1988. El complejo psicotrópico en Solcor-3 (San Pedro de Atacama). Estudios Atacameños 9:61-98. 
_ _ _ 2001. Iconografía Tiwanaku en la parafernalia inhalatoria de los Andes Centro-Sur. Boletín de Arqueología Pontificia Universidad Católica del Perú 5:427-454.

Torres, C.M. and W.J. Conklin 1995. Exploring the San Pedro de Atacama/Tiwanaku relationship. In Andean Art: Visual Expression and its Relation to Andean Beliefs and Values, edited by P. Dransart, pp. 78-108. Avebury, Hampshire, England.

Torres-Rouff, C. 2002. Cranial vault modification and ethnicity in Middle Horizon San Pedro de Atacama, Chile. Current Anthropology 43:163-171.

_. _ 2008 The influence of Tiwanaku on life in the Chilean Atacama: mortuary and bodily perspectives. American Anthropologist 110:325-337.

Torres-Rouff, C. and M.A. Costa 2006. Interpersonal violence in prehistoric San Pedro de Atacama, Chile: behavioral implications of environmental stress. American Journal of Physical Anthropology 130:60-70.

Torres-Rouff, C., M.A. Costa, and A. Llagostera 2005. Violence in times of changes: the Late Intermediate Period in San Pedro de Atacama. Chungara Revista de Antropología Chilena 37:75-83.

Uribe, M. 1997. La alfarería de Caspana y su relación con la prehistoria tardía de la subárea circumpuneña. Estudios Atacameños 14:243-262.

- _ _ 2002. Sobre alfarería, cementerios, fases y procesos durante la prehistoria tardía del desierto de Atacama (800-1600 DC). Estudios Atacameños 22:7-31.

- _ _ 2004. El Inka y el poder como problemas de la arqueología del Norte Grande de Chile. Chungara Revista de Antropología Chilena 36:313-324.

- _ - 2006. Sobre cerámica, su origen y complejidad social en los Andes del desierto de Atacama, norte de Chile. In Esferas de Interacción Prehistóricas y Fronteras Nacionales Modernas: Los Andes Sur Centrales, edited by H. Lechtman, pp. 449-494. Institute of Andean Research and Instituto de Estudios Peruanos, Lima.
_ _ _ 2009. El período Formativo de Tarapacá y su cerámica: Avances sobre complejidad social en la costa del norte grande de Chile (900 AC-800 DC). Estudios Atacameños 37:5-27.

Uribe, M. and L. Adán 2005. Arqueología e Historia: cultura y evolución social en el desierto Atacama (900-1.700 DC). In Actas del XVI Congreso Nacional de Arqueología Chilena, pp. 263274. Museo de Historia Natural de Concepción, Dirección de Bibliotecas, Archivos y Museos, Sociedad Chilena de Arqueología. Ediciones Escaparate, Concepción.

Uribe, M. and C. Agüero 2001. Alfarería, textiles y la integración del norte grande de Chile a Tiwanaku. Boletín de Arqueología Pontificia Universidad Católica del Perú 5:397-426.

- _ - 2004. Iconografía, alfarería y textilería Tiwanaku: Elementos para una revisión del Período Medio en el Norte Grande de Chile. Chungara Revista de Antropología Chilena 36:1055-1068.

Uribe, M. and P. Ayala 2004. La alfarería de Quillagua en el contexto formativo del Norte Grande de Chile (1000 a.C.-500 d.C.). Chungara Revista de Antropología Chilena 36:585-597.

Uribe, M. and C. Carrasco 1999. Tiestos y piedras talladas de Caspana: la producción alfarera y lítica en el período Tardío del Loa Superior. Estudios Atacameños 18:55-72.

Uribe, M., L. Adán, and C. Agüero 2002. El dominio del Inka, identidad local y complejidad social en las tierras altas del desierto de Atacama, Norte Grande de Chile (1450-1541 DC). Boletín de Arqueología Pontificia Universidad Católica del Perú 6:301-336.

_ _ _ 2004. Arqueología de los períodos Intermedio Tardío y Tardío de San Pedro de Atacama y su relación con la cuenca del río Loa. Chungara Revista de Antropología Chilena 36:943-956.

Varela, V., M. Uribe, and L. Adán 1993. La cerámica arqueológica del sitio 'pukara' de Turi: 02-TU-001. Actas del XII Congreso Nacional de Arqueología Chilena, pp. 107-122. Museo Regional de la Araucanía, Temuco.

\section{Note}

1 Although found in the Hubbe et al. 2011 publication, no dates from the Toconao Oriente site were included in the Hubbe and Torres-Rouff 2011 chapter. These dates were not considered here because Toconao Oriente, although an important site in local archaeology, is located $40 \mathrm{~km}$ to the south of the San Pedro oases. The prehistoric relationship between communities in Toconao and San Pedro are still little understood. 
